\title{
PELATIHAN PENGOLAHAN DATA HASIL PENGUKURAN WATERPASS, THEODOLIT, TOTAL STATION BAGI GURU TEKNIK KONSTRUKSI DAN PROPERTI SMK WILAYAH KABUPATEN JOMBANG \& SEKITARNYA
}

\author{
Elizabeth Titiek Winanti ${ }^{1 *}$, Indiah Kustini ${ }^{1}$, R Endro Wibisono ${ }^{1}$, Djoni Irianto ${ }^{1}$, \\ Danayanti Azmi Dewi Nusantara ${ }^{1}$, Nurhayati Aritonang ${ }^{1}$
}

${ }^{1}$ Jurusan Teknik Sipil, Universitas Negeri Surabaya, Surabaya, Indonesia

*Email: titiekwinanti@unesa.ac.id

\section{Informasi Artikel Abstrak}

Kata kunci:

Pengolahan pengukuran dengan alat Waterpass, Theodolit, Total Station.

Diterima: 30-11-2021

Disetujui: 20-01-2022

Dipubikasikan: 28-01-

2022

Keywords:

Data processing, measurement with tools Waterpass, Theodolite, Total Station
Pelatihan di latar belakangi untuk menyamakan kompetensi kelulusan siswa pada mata pelajaran tersebut, terkait adanya perkembangan operasional alat dan pengembangan alat dari manual ke idital. Sebagai masalah 1) Guru sebagai pendidik selalu berusaha menyiapkan lulusan SMK sebagai tenaga kerja dikonstruksi, 2) selalu menyesuaikan diri dari perkembangan teknologi pada pekerjaan lapangan, 3) pentingnya fungsi alat UT di lapangan sebagai alat sarana penetapan titik duga, cek kelurusan, ketegakan yang dikehendaki pada bangunan gedung. Tujuan PKM:1) menyamakan pemahaman kompetensi mata pelajaran tersebut bagi kelulusan SMK, 2) memberi pemahaman informasi perkembangan teknologi alat pengukuran, 3) pemahaman operasional dan pengolahan data alat pengukuran di lapangan yang hasil pengukurannya sangan berfungsi untuk pembangunan. Rumusan masalah pelatihan 1) bagaimanakah peningkatan pemahaman mengolah data hasil pengukuran waterpass, theodolit, total station 2) bagaimanakah kepuasan materi dan pemateri pada pelatihan. Metode pelatihan ceramah, mengerjakan tugas, pemberian pre tes dan post tes serta pengisian angket kepuasan. Hasil Pelatihan:1) pemahaman materi, peserta sudah mempunyai kemapuan cukup karena menjawab pertanyaan dengan benar $58 \%$, 2) Peningkatan pemahaman setelah pelatihan ada kenaikan sedikit sekitar $18 \%$ 3) Pemahaman materi operasional alat total stasion sebesar $40 \%$, 4) Peserta $95 \%$ menyatakan sangat puas pada materi yang diberikan. 5) Kepuasan pada pemateri pelatihan $88 \%$.

\section{Abstract}

The background of the training is to equalize the competence of students graduation in these subjects, related to the development of tool operations and the development of tools from manual to ideal. As problems 1) Teachers as educators always try to prepare SMK graduates as construction workers, 2) always adapt to technological developments in field work, 3) the importance of the function of the UT tool in the field as a means of determining the guessing point, checking straightness, desired uprightness. 
on buildings. The objectives of PKM are: 1) to equalize the understanding of the competence of these subjects for graduation from SMK, 2) to provide an understanding of information on the development of measurement tool technology, 3) to understand the operational and data processing of measurement tools in the field whose measurement results are very useful for development. The formulation of the training problem 1) how to increase understanding of processing data from the measurement of the waterpass, theodolite, total station 2) how is the satisfaction of the material and presenters in the training. Lecture training methods, doing assignments, giving pre-test and post-test and filling out a satisfaction questionnaire. Training Results: 1) understanding of the material, participants already have sufficient ability because they answered the questions correctly 58\%,2) Increased understanding after training there was a slight increase of about $18 \%$ 3) Understanding of operational material for total station equipment by $40 \%$, 4) Participants $95 \%$ very satisfied with the material provided. 5) Satisfaction with the training presenters $88 \%$.

\section{PENDAHULUAN}

Pengabdian masyarakat di SMK ini dilatarbelakangi terkait dengan UU No.14/2005 yang menyatakan guru adalah pendidik profesional dengan tugas utama mendidik, mengajar, membimbing, melatih, menilai, mengevaluasi peserta didik pada pendidikan usia dini, jalur pendidikan formal, pendikan dasar, pendidikan menengah. Guru harus professional pemahaman materi mata pelajaran yang akan di ajarkan ke peserta didik. Khusus pada Sekolah Mengah Kejuruan (SMK) menjadi pusat pendidikan dan pelatihan yang unggul, berwawasan lingkungan, menghasilkan tamatan yang kompeten mandiri berbudi luhur. Sebagai upaya mewujukan tujuan SMK, diantaranya pada setiap mata pelajaran diperlukan peningkatan adan pengembangan: 1) kualitas manajemen, sumber daya manusia (SDM) dan sarana, 2) kualitas pelayanan pendidikan dan pelatihan. mewujudkan warga sekolah peduli dan berbudaya lingkungan, 3) kemampuan tamatan berwirausaha, keterserapan di dunia usaha/Industri dan perguruan tinggi

Salah satu pengembangan materi mata pelajaran yang penerapannya terkait dengan konstuksi yaitu mata pelajaran ilmu ukur tanah (IUT). Mata pelajaran IUT merupakan matapelajaran praktik yang menggunakan alat ukur optik. Alat ukur ini dilengkapi dengan perlengkapan optik sehingga mendapatkan hasil perhitungan yang tepat dan lebih detail jika dibandingkan dengan alat ukur sederhana. Alat ukur optik ini terdiri dari beberapa alat yang dirangkai dalam satu buah alat, sehingga dapat mengukur lebih dari satu pengukuran. Jenis alat tersebut waterpas, theodolite dan total stasion. Hasil pengukuran dengan menggunakan alat ukur tanah ini, sebagai sarana awal pembangunan konstruksi baik untuk bangunan gedung, bangunan air, drainase, jalan, pembukaaan lahan, dan lain lain. Dalam buku (Wongsotjitro, 1980) terkait dengan surveying dan building sites lebih detail dijelaskan tata caranya. 
Menurut (Amir, 1998) menyatakan bahwa alat ukur tanah waterpas, berfungsi untuk mengukur beda tinggi dari satu titik atau lebih, penggunaan waterpas saat ini sangat luas. Dalam buku (Muhamadi, 1987) terkait materi beda tinggi terdapat beberapa syarat dalam menggunakan waterpas, yaitu syarat dinamis (sumbu 1 vertikal) dan syarat statis (garis yang mendatar pada bagian diafragma sejajar sumbu 1, garis nivo tegak lurus sumbu 1, garis bidik pada teropong sejajar dengan garis arah nivo). Theodolith alat yang berfunsi untuk pengukuran polygon, pemetaan situasi dan juga pengamatan matahari. Tidak hanya itu, theodolit juga bisa berfungsi seperti PPD jika sudut vertikalnya diubah menjadi $90^{\circ}$. Teropong yang ada di theodolit, membuatnya dapat membidik ke segala arah. Pada konstruksi bangunan, teodolit dapat berfungsi untuk menentukan sudut siku -siku pada pondasi dan juga mengukur ketinggian bangunan bertingkat. Total Station (Sosrodarsono \& Takasaki, 1996), merupakan teknologi alat yang menggabungkan secara elektornik antara teknologi theodolit dengan teknologi EDM (electronic distance measurement). EDM merupakan alat ukur jarak elektronik yang menggunakan gelombang elektromagnetik sinar infra merah sebagai gelombang pembawa sinyal pengukuran dan dibantu dengan sebuah reflektor berupa prisma sebagai target (alat pemantul sinar infra merah agar kembali ke EDM). Total Station merupakan alat ukur elektronik yang berasal dari pengembangan theodolite, alat ini dilengkapi oleh pengukuran jarak dan sudut secara elektronik dengan bantuan dari reflektor sebagai target dan pengganti rambu ukur. Untuk mempermudah penggunaan, total station perlu dihubungankan dengan komputer. Fungsi total station yaitu dapat digunakan untuk menghitung jarak, arah, titik koordinat dan juga beda tinggi secara elektronis/otomatis. Tampilan hasil pengukuran pada liquid crystal display (LCD) dan penyimpanan data pada alat maupun dengan eksternak harddisk. Perhitungan secara cepat untuk komponen jarak horisontal dan vertikal, elevasi dan koordinat titik yang diamati. Total Station dapat digunakan pada sembarang tahapan survei, baik survey pendahuluan, survei titik kontrol dan survey pematokan. Menurut (Basuki, 2011) teknologi pengukuran dan pemetaan teristris yang dibutuhkan bagi keperluan pembangunan fisik, kebutuhan peta (umum maupun khusus) semakin dibutuhkan, mulai dari perencanaan, pelaksanaan, hingga pemeliharaan pasca pembangunan. Menurut (Wolf., 1986) sebelum konstruksi dimulai surveyor melakukan pemindahan garis tengah ke tanah.

Mengingat pentingnya fungsi dari penggunaan alat tersebut pada pembangunan kontruksi terimbas dengan lulusan SMK yang harus terserap sebagai tenaga trampil tingkat dasar di lapangan pihak Cabang Dinas (Cabdin) pendidikan Wilayah Jombang mempunyai gagasan untuk menyamakan kompetensi kelulusan pada mata pelajaran tersebut. Sebagai usaha upaya menyamakan kompetensi siswa, diperlukan terlebih dulu persamaan pemahaman pengembangan dari materi mata diklat bagi guru program Guru Teknik Konstruksi dan Properti di wilayah cabang dinasnya, untuk mengadakan pelatihan. Cabdin Pendidikan Wilayah Jombang memanfaatkan hubungan kerjasama antara SMK/MOU dengan Fakultas Teknik yang di wakili oleh sekolah SMKN Kudu Jombang sebagai koordinator SMK wilayah sekitar Jombang, mengajukan permohonan pada fakultas Teknik sebagai 
pencetak Lembaga Pendidikan Tenaga Kependidikan (LPTK) khususnya guru SMK Program Keahlian Teknik Konstruksi dan Properti untuk mengadakan pelatihan pengopersian alat IUT tersebut.

Analisisis Situasi dari sumber profil SMKN Jurusan Bisnis Konstruksi dan Properti di Wilayah Dinas Jombang yang meliputi Mojokerto, Kudu, Jombang, Nganjuk, Madiun, Balong Bendo, Pasuruan, Trenggalek, Jenangan Ponorogo, menyatakan "semua saranan dan prasarana, manajemen dan lainnya terpenuhi dan sudah memenuhi persyaratan yang ditentukan", sehingga agriditasinya terpenuhi mendapatkan penilaian Akriditasi sangat baik dengan nilai "A". Jumlah Rombel lulusan harus kompeten di bidangnya supaya bisa terlaksana sehingga hanya menerima satu rombel. Produksi SMKN tersebut rerata berproduksi 1) Pembuatan Kusen dan daun pintu, 2) Gambar rumah sederhana dan lantai 1 beserta detail, 3) Pengukuran beda tinggi, situasi, sudut vertical dan luas areal, 4) Perhitungan $\mathrm{RAB}$ konstruksi tingkat rendah dan lain lainya yang sesuai pesanan yang terkait dengan kompetensi lulusan. Jumlah Guru IUT yang membimbing produksi pengukuran beda tinggi, situasi, sudut vertical dan luas areal, rata-rata ada dua guru dengan status sebagian besar non PNS (dari data peserta)

Permasalahan yang ada Di SMKN diantaranya : 1) Adanya covid 19, tidak mempengaruhi pembangunan sehingga pengembangan teknologi pelaksanaan pembangunan dan informasi tidak terhambat, SMK melalui pembelajaran harus menyiapkan tenaga kerja dasar yang trampil dan kompeten, 2) Pembangunan konstruksi dengan pengembangan teknologi dapat dikerjakan lebih cepat dan efektif sehingga akan memerlukan tenaga trampil dasar dengan persamaan kompetensi, khususnya dalam pekerjaan pengkuran beda tinggi, pengukuran horizontal tegak lurus, pengukuran luas sesuai yang ada di lapangan, 3) Guru harus profesional dengan memiliki kualifikasi akademik, menguasai empat kompetensi (pedagogik, kepribadian, sosial dan profesional) memerlukan berbagai sertifikat keahlian baik lokal, nasional internasional, pada pemahaman pengembangan materi di lapangan melalui pelatihan, 4) Kompetensi dasar lulusan SMK untuk pekerjaan di lapangan harus sesuai dengan pengembangan teknologi dan standart, sehingga guru dalam pemberian materi yang peneraapan di lapangan juga harus sama, minimum untuk walayah cabang dinas, 5) Adanya pengembangan alat ukur tanah ukur waterpass dan theodolith yang pengukuran dan pengolahan data sesuai pengembangan teknologi dan adanya penggunaan secara manual menjadi digital yang dikenal dengan nama alat total stasion yang kurang dipahami oleh guru mata diklat dengan benar. Sebagai prioritas untuk mengatasi permasalahan pelatihan perlunya pemahaman guru SMK dalam pengopersian alat dan pengolahan data alat ukur tanah, akibat perkembangan teknologi pembangunan konstruksi dengan berbagai permasalahan di lapangan.

Dari analisis situasi tersebut maka tujuan dari pelatihan adalah: 1) menyamakan pemahaman kompetensi mata pelajaran tersebut bagi kelulusan SMK, 2) memberi pemahaman informasi 
perkembangan teknologi alat pengukuran pada lapangan, 3) pemahaman operasional dan pengolahan data alat pengukuran di lapangan yang hasil pengukurannya sangan berfungsi untuk pembangunan. Rumusan masalah pelatihan : Bagaimanakah peningkatan pemahaman pengopersian alat dan pengolahan data, akibat perkembangan teknologi pembangunan konstruksi bagi guru program Keahlian Teknik Konstruksi dan Properti. Guru sebagai pendidik selalu berusaha menyiapkan lulusan SMK sebagai tenaga kerja dikonstruksi, selalu menyesuaikan diri dari perkembangan teknologi pada pekerjaan lapangan, pentingnya fungsi alat Ukur Tanah di lapangan sebagai alat sarana penetapan titik duga, cek kelurusan, ketegakan yang dikehendaki pada bangunan gedung. menyamakan pemahaman kompetensi mata pelajaran tersebut bagi kelulusan SMK, memberi pemahaman informasi perkembangan teknologi alat pengukuran, pemahaman operasional dan pengolahan data alat pengukuran di lapangan yang hasil pengukurannya sangan berfungsi untuk pembangunan. Rumusan masalah pelatihan, bagaimanakah peningkatan pemahaman mengolah data hasil pengukuran waterpass, theodolit, total station, bagaimanakah kepuasan materi dan pemateri pada pelatihan.

Kepakaran Jurusan Teknik Sipil bisa di katakana semua yang terkait dengan managemen, sarana dan prasarana hitungan dan lainnya yang terkait dengan pembangunan, baik untuk merencanakan dan memecahkan masalah pembangunan dapat diselesaikan oleh tenaga ahli di jurusan teknik sipil. Selain tersebiu tenaga ahli selain melaksanakan pembelajaran terkait dengan LPTK, juga selalu siap untuk mengadakan pelatihan dan memberi pelatihan sesuai dengan ilum kepakarannya. Tenaga ahli selain melakukan pembelajaran, melakukan penelitian dan pengabdian masyarakat yang relevan dengan kepakarannya. Upaya-upaya yang pernah dilakukan mengadakan pelatihan bagi guru di SMK, karyawan kantor/dipartemen, wirausaha baru dan lainnya. Selanjutnya di uraikan dari hasil pelatihan yang sudah dilaksanakan pada ahir tahun 2021 yaitu Pelatihan Pengolahan Data Hasil Pengukuran Waterpass, Theodolit, Total Station Bagi Guru Teknik Konstruksi Dan Properti Smk Wilayah Kabupaten Jombang \& Sekitarnya.

\section{METODE}

Metode pelaksanaan untuk mengetahui adanya peningkatan pemahaman materi menggunakan pre-test dan post-test, sedangkan untuk mngetahui keberhasilan pelaksanaan PKM melalui angket kepuasan materi dan pemateri. Instrumen tes ada 31 butir dengan 7 indikator (dijelaskan pada kaimat berikutnya). Tahapan pelaksanaan kegiatan PKM yang diselenggarakan diawali dengan: 1) koordinasi, diantaranya kesepakatan materi mengacu pada silabus, metode pelaksanaan ditetapkan secara daring, 2) persiapan dengan kegiatan pembuatan grup WhasApp, menyiapkan amplikasi Zoom, Google drive, 3) pelaksanaan pemahaman materi sesuai jadwal. Setiap hari peserta diminta mengisi daftar hadir, angket kepuasan pada link melalui WhatsApp dengan jawaban ya atau tidak. Indikator kepuasan materi yang disampaikan antara lain materi: bermanfaat dan memberi motivasi, mudah dipahami, sesuai dengan kegiatan. Indikator kepuasan pemateri: tentang kesiapan penyampaian 
materi, ketepatan waktu kehadiran pemateri, upaya membangkitkan minat peserta pada materi yang di sampaikan. Peserta juga setiap hari diberi tugas dan di kumpulkan pada hari berikutnya pada google drive yang sudah disediakan. Hari pertama pelaksanaan pelatihan diadakan pre-test dan akhir pelatihan hari ke tiga peserta mengerjakan post-test dengan bentuk soal pilihan ganda, pengisian pada link yang dibuat pada WhatsApp . Penguasaan materi post-tes meliputi: 1) Persyaratan Pengukuran dan K 3 alat, 2) Persiapan Pengukuran Alat, 3) Pengukuran Profil, 4) Pengolahan Data Pengukuran 4) Mengevaluasi Hasil Pengukuran, 5) Pemrograman alat TS, 6) Pengolahan Data Pengukuran alat TS 7) Mengevaluasi hasil pengukuran. Metode pemahaman materi pelatihan dengan ceramah,demosntrasi, latihan, mengerjakan tugas, diskusi/tanya jawab, secara daring melalui link Zoom.

\section{HASIL DAN PEMBAHASAN}

Kegiatan pelatihan bagi guru terkait dengan mata diklat ilum ukur tanah yang dilakukan dengan peserta 49 guru dari 10 SMKN Wilayah Cabdin Pendidikan Jombang dilaksanakan selama 3 hari mulai jam 8.00 sampai dengan jam 14.00 terlaksana sesuai dengan jadwal yang ditunjukan pada Tabel 1. Sebagai contoh kegiatan ditunjukan ditunjukan pada Gambar 1.

Tabel .1 Jadwal dan Materi PKM Pelatihan Pengolahan Data dengan Alat Ukur Tanah

\begin{tabular}{|c|c|c|c|c|}
\hline Tanggal & No & Materi & Narasumber & Waktu \\
\hline & 1 & $\begin{array}{l}\text { Sambutan Pembukaan Tim PKM } \\
\text { Kepala Sekolah SMK Kudu Jombang } \\
\text { Kepala Cabang Dinas Jombang } \\
\text { Dekan Fakultas Teknik Unesa }\end{array}$ & $\begin{array}{l}\text { Prof. Dr., E. Titiek Winanti, MS. } \\
\text { Drs. Khasanuddin, M.MPd } \\
\text { Drs. Trisilo Budi Prasetyo, MM } \\
\text { Dr. Maspiyah, M . Kes }\end{array}$ & $08.00-08.30$ \\
\hline & 2 & Pre Test & Tim PKM & $08.30-09.00$ \\
\hline Hari Ke 1 & 3 & $\begin{array}{l}\text { Pengantar Alat Ukur Waterpass } \\
\text { (Pemutaran Video) }\end{array}$ & Endro W., S.Pd.MT. dan Tim & $09.00-09.30$ \\
\hline \multirow{4}{*}{$\begin{array}{c}1 \\
\text { September } \\
2021\end{array}$} & 4 & Persyaratan Pengukuran dan K3 & Choirul Umam, M.Pd.MT & $09.30-11.00$ \\
\hline & 5 & $\begin{array}{l}\text { Pengukuran dengan alat Waterpass } \\
\text { Pengass }\end{array}$ & sda & $11.00-12.00$ \\
\hline & 6 & $\begin{array}{l}\text { Pengolahan Data hasil pengukuran dg } \\
\text { alat Waterpass }\end{array}$ & sda & $12.00-13.00$ \\
\hline & 7 & $\begin{array}{l}\text { Diskusi dan aplikasi lapangan dan } \\
\text { pemberian tugas }\end{array}$ & $\begin{array}{l}\text { Dra. Indiah Kustini, MT. } \\
\text { TimTim }\end{array}$ & $13.00-14.00$ \\
\hline & 1 & Pengantar Alat Ukur Tanah Theodolit & $\begin{array}{l}\text { Choirul Umam M., M. Pd.MT., } \\
\text { Rahmat Hidayat, S.Pd. dan Tim }\end{array}$ & $08.00-08.30$ \\
\hline & 2 & Persyaratan Pengukuran dan K3 alat & Rahmat Hidayat ,S.Pd. dan Tim & $08.30-09.30$ \\
\hline Hari Ke 2 & 3 & $\begin{array}{l}\text { Perbedaan alat Theodolit dan } \\
\text { Waterpass }\end{array}$ & $\begin{array}{l}\text { Choirul Umam M.Pd.MT., } \\
\text { Rahmat Hidayat, S.Pd. dan Tim }\end{array}$ & $09.30-10.00$ \\
\hline \multirow{4}{*}{$\begin{array}{c}2 \\
\text { September } \\
2021\end{array}$} & 4 & Pengukuran dengan alat Theodolit & Endro W., S.Pd.,M.T. dan Tim & $10.00-12.00$ \\
\hline & 6 & $\begin{array}{l}\text { Pengolahan data pengukuran } \\
\text { dengan alat }\end{array}$ & sda & $12.00-13.00$ \\
\hline & 7 & $\begin{array}{l}\text { Diskusi dan aplikasi lapangan dan } \\
\text { pemberian tugas }\end{array}$ & $\begin{array}{l}\text { Danayanti Azmi D. N., S,T dan } \\
\text { Tim }\end{array}$ & $13.00-14.00$ \\
\hline & 1 & $\begin{array}{l}\text { Pengantar Alat Ukur Tanah Total } \\
\text { Station }\end{array}$ & Rahmat Hidayat, S.Pd. dan Tim & $08.00-08.30$ \\
\hline
\end{tabular}




\begin{tabular}{cclcc}
\hline Hari Ke 3 & 2 & $\begin{array}{l}\text { Persyaratan Pengukuran dan K3 alat } \\
\text { Total Station }\end{array}$ & sda & $08.30-09.30$ \\
3 & 3 & Penyetelan alat Total Station & sda & $09.30-10.00$ \\
September & 4 & Pengukuran dengan alat Total Station & sda & $10.00-10.30$ \\
2021 & 5 & Pengolaha data hasil pengukuran & sda & $10.30-11.00$ \\
& 6 & $\begin{array}{l}\text { Diskusi dan aplikasi lapangan dan } \\
\text { penutup hari ke 3 dan pemberian tugas }\end{array}$ & Dra. Indiah Kustini, M.T & $13.00-14.00$ \\
\hline
\end{tabular}
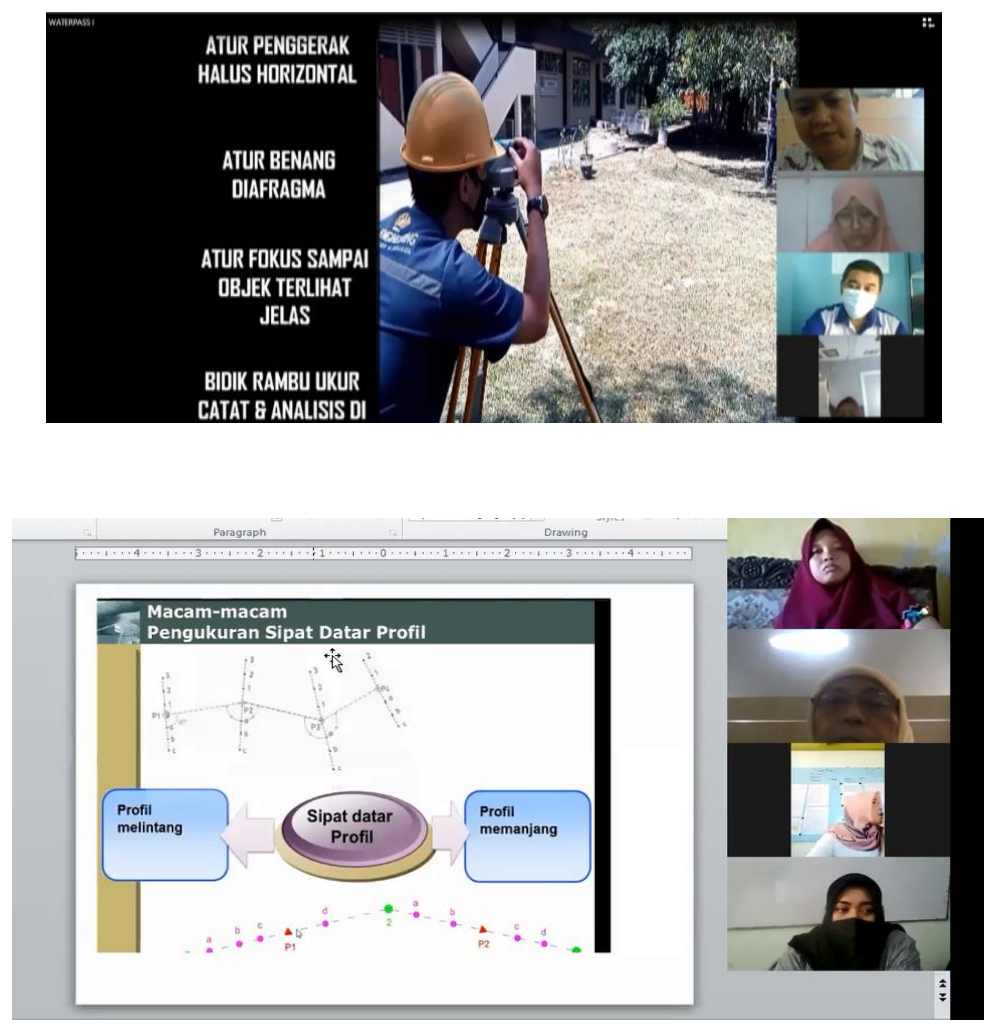

Diskusi Pengolahan Data Hasil Pengukuran dengan Alat Ukur Waternass

\begin{tabular}{|c|c|c|c|c|c|c|c|}
\hline \multirow{2}{*}{ Titik } & \multicolumn{2}{|c|}{ Pembacaan rambu } & \multicolumn{2}{|c|}{ Jarak } & \multirow{2}{*}{ Beda tinggi } & \multirow{2}{*}{ koreksi } & \multirow{2}{*}{ Tinggi titik } \\
\hline & Belakang & Muka & Belakang & Muka & & & \\
\hline & 2.026 & & & & & & \\
\hline & 1.891 & & $\ldots \ldots \ldots \ldots . .$. & & & & 100 \\
\hline & 1.756 & & & & & & \\
\hline \multirow[t]{4}{*}{ P1 } & & & & & $\ldots$ & $\ldots \ldots$ & \\
\hline & 1.934 & 1.7490 & & & & & \\
\hline & 1.784 & 1.6240 & ............... & ……........ & & & ……........ \\
\hline & 1.634 & 1.4990 & 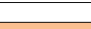 & 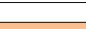 & & & $x_{1}$ \\
\hline \multirow[t]{4}{*}{$\mathrm{P}_{2}$} & & & & & & & \\
\hline & 1.671 & 1.3870 & & & & & \\
\hline & 1.561 & 1.2470 & $\ldots \ldots \ldots \ldots \ldots$ & ................. & & & $\ldots \ldots \ldots \ldots . . .$. \\
\hline & 1.451 & 1.1070 & & & & & \\
\hline \multirow[t]{4}{*}{ P3. } & & & & & & ....... & \\
\hline & 2.098 & 1.8230 & & & & & \\
\hline & 1.973 & 1.6880 & ................. & $\ldots \ldots \ldots \ldots \ldots$ & & & ................. \\
\hline & 1.848 & 1.5530 & & & & & \\
\hline \multirow[t]{4}{*}{ P4 } & $1.0+10$ & & & & $\ldots \ldots \ldots \ldots \ldots$ & $\ldots \ldots \ldots \ldots \ldots$ & \\
\hline & 1.824 & 1.6850 & & & & & \\
\hline & 1.684 & 1.5400 & $\ldots \ldots \ldots \ldots \ldots . . .$. & $\ldots \ldots \ldots \ldots \ldots . . .$. & & & $\ldots \ldots \ldots \ldots \ldots$ \\
\hline & 1.544 & 1.3950 & & & & & \\
\hline \multirow[t]{4}{*}{ P5 } & t.th & & & & $\ldots \ldots \ldots \ldots \ldots$ & $\ldots \ldots \ldots \ldots \ldots$ & \\
\hline & 1.990 & 1.9680 & & & & & \\
\hline & 1.835 & 1.8430 & $\ldots \ldots \ldots \ldots \ldots \ldots . . . .$. & ………....... & & & $\ldots \ldots \ldots \ldots \ldots . . .$. \\
\hline & 1.680 & 1.7180 & & & & & \\
\hline \multirow[t]{3}{*}{$\mathrm{P} 6$} & & 1.100 & & & $\ldots \ldots \ldots \ldots$ & $\ldots \ldots \ldots \ldots . . . . .$. & \\
\hline & & 2.9350 & & & & & \\
\hline & & $\begin{array}{r}2.7900 \\
2.6450\end{array}$ & - & ….......... & & & $\ldots \ldots \ldots \ldots$ \\
\hline & $\sum \mathrm{tb}$ & $\sum \operatorname{tm}$ & $\sum \mathrm{db}$ & $\sum \mathbf{d m} \mathbf{n}$ & $\sum \mathrm{h}$ & & \\
\hline & $\ldots \ldots \ldots \ldots . . .$. & ................. & ……........... & $\ldots \ldots \ldots \ldots \ldots$ & ………......... & $\ldots \ldots \ldots \ldots \ldots$ & \\
\hline
\end{tabular}

Tugas Pengolahan Data Hasil

Pengukuran Keliling

Gambar 1. Kegiatan Pelaksanaan Pelatihan Hari ke Satu 
Pencapaian tujuan pemahaman materi dilakukan tes pemahaman materi dengan 31 butir tes pilihan ganda dari 7 indikator, dikerjakan dengan lama waktu 20 menit. Hasil pre tes dari 49 peserta, didapatkan nilai rata rata dengan jawaban benar $58 \%$, yang ditunjukan pada Tabel 2. Hasil post tes dari 47 peserta dengan jawaban benar didapatkan nilai rata rata $72 \%$. Data tersebut menyatakan hasil pemahaman materi setelah pelatihan ada kenaikan tingkat pemahaman sebesar $14 \%$, dengan nilai hasil setiap indikator juga ditunjuk pada Tabel 2.

Tabel 2. Hasil Rekap Data Pemahaman Materi Pelatihan Alat Ukur Tanah

\begin{tabular}{llccc}
\hline \multirow{2}{*}{ No } & \multicolumn{1}{c}{ Pemahaman Materi } & \multicolumn{2}{c}{$\begin{array}{c}\text { Bobot } \\
\text { materi }\end{array}$} & $\begin{array}{c}\text { Pre tes } \\
\text { Post tes }\end{array}$ \\
\cline { 3 - 5 } & & $\%$ & $\%$ & $\%$ \\
\hline 1 & Persyaratan Pengukuran dan K 3 alat & 13 & 10 & 11 \\
2 & Persiapan Pengukuran Alat & 13 & 10 & 11 \\
3 & Pengukuran Profil & 13 & 10 & 11 \\
4 & Pengolahan Data Pengukuran & 16 & 8 & 12 \\
5 & Mengevaluasi Hasil Pengukuran & 10 & 5 & 6 \\
6 & Pemrograman alat TS, & 10 & 5 & 7 \\
7 & Pengolahan Data Pengukuran alat TS & 13 & 5 & 7 \\
8 & Mengevaluasi Hasil pengukuran alat TS & 13 & 5 & 7 \\
9 & Jawaban salah & 0 & 42 & 28 \\
& Jawaban benar & 100 & 58 & 72 \\
& Total & 100 & 100 & 100 \\
\hline
\end{tabular}

Keberhasilan kegiatan pelatihan pelaksanaan PKM dengan metode pemberian angket kepuasan dengan instrument isian 3 indikator, peserta menjawab setuju "ya" $95 \%$. Tiga indikator kepuasan materi tersebut adalah: bermanfaat dan memberi motivasi, mudah dipahami, ditunjukan pada Tabel 3 . Kesan untuk pemateri tentang: kesiapan penyampaian materi, ketepatan waktu kehadiran pemateri, upaya membangkitkan minat peserta, menjawab kurang $11 \%$ menjawab kurang, cukup $47 \%$ dan baik $42 \%$., ditunjukan pada Tabel 4

Tabel 3. Hasil Rekap Data Kepuasan Materi Pelatihan Alat Ukur Tanah

\begin{tabular}{ccccccc}
\hline \multirow{2}{*}{ No } & \multirow{2}{*}{ Kepuasan Peserta Terhadap } & Jumlah & \multicolumn{2}{c}{ Jawaban } & \multicolumn{2}{c}{ Jawaban (\%) } \\
\cline { 5 - 7 } & Jawaban & ya & tidak & ya & tidak \\
\hline & $\begin{array}{l}\text { Materi yang disampaikan } \\
\text { bermanfaat dan memberi }\end{array}$ & 137 & 124 & 13 & 90.30 & 9.49 \\
$\begin{array}{l}\text { motivasi } \\
1\end{array}$ & 137 & 129 & 8 & 94.20 & 5.84 \\
$\begin{array}{l}\text { Materi yang disampaikan } \\
\text { mudah dipahami }\end{array}$ & 137 & 137 & 0 & 100 & 0.00 \\
\hline $\begin{array}{l}\text { Materi yang disampaikan sesuai } \\
\text { dengan kegiatan }\end{array}$ & 137 & 130 & 7 & 95 & 5 \\
\hline Kepuasan Materi & & & & & \\
\hline
\end{tabular}


Tabel 4. Hasil Rekap Data Kepuasan Pemateri Pelatihan Alat Ukur Tanah

\begin{tabular}{clccccccc}
\hline No & \multirow{2}{*}{ Kepuasan Peserta Terhadap } & Jumlah & \multicolumn{3}{c}{ Kriteria } & \multicolumn{3}{c}{ Kriteria \% } \\
\cline { 3 - 9 } & jawaban & kurang & cukup & baik & kurang & cukup & baik \\
\hline 1 & $\begin{array}{l}\text { Kesiapan penyampaian materi } \\
\text { Ketepatan waktu kehadiran }\end{array}$ & 137 & 13 & 69 & 55 & 9.49 & 50.36 & 40.15 \\
2 & 137 & 15 & 63 & 60 & 10.95 & 45.99 & 43.80 \\
pemateri & 137 & 18 & 62 & 57 & 13.14 & 45.26 & 41.61 \\
& $\begin{array}{l}\text { Upaya membangkitkan minat } \\
\text { peserta pada materi yang di } \\
\text { sampaikan }\end{array}$ & 137 & 15 & 65 & 57 & 11.19 & 47.20 & 41.85 \\
\hline & \multicolumn{1}{c}{ Kepuasan Pemateri } & & & & & & & \\
\hline
\end{tabular}

Peserta pelatihan 49 Guru Teknik Konstruksi dan Properti SMK Wilayah Kabupaten Jombang \& Sekitarnya. Pemahaman materi melalui pre- tes dan akhir pelatihan (post tes) ada kenaikan $18 \%$ dari hasil pre tes pada peserta sebelum pelatihan yang menjawab benar adalah $58 \%$, sesudah pelatihan dengan pemberian post tes pada peserta yang menjawab benar adalah $72 \%$. Hasil pre tes $58 \%$ dengan arti kemampuan peserta sudah cukup karena yang menjawab benar lebih dari $50 \%$ peserta pelatihan. Hal ini disebabkan peserta adalah guru, minimum sudah mempunyai pemahaman tentang alat ilmu ukur tanah meskipun bukan guru mata pelajaran yang terkait. Peningkatan pemahaman setelah pelatihan $14 \%$ dikatakan kecil karena : a) Kompetensi dasar (KD) materi IUT ada $12 \mathrm{KD}$, tidak seimbang dengan waktu yang disediakan, meskipun sifatnya meriviu kembali, b) Pemahaman kogniktip perlu banyak latihan dan contoh selain teori banyak hitungan matematikanya, c) Tidak ada waktu bagi peserta presentasi langkah kerja sebelum pengukuran, saat pengukuran, masalah pengukuran di lapangan baik untuk K3 alat dan pengukurannya, d) pemberian materi terlalu padat. Peserta pelatihan untuk pemahan operasional alat total stasion (TS) masih agak kurang, terbukti dari jawaban yang kurang benar sekitar $42 \%$, hal ini disebabkan alat tersebut merupakan alat pengembangan dari alat waterpas dan theodolit yang di jadikan satu, dengan terlebih dahulu melakukan pembidikan pada alat diafragma dan sebelum pengoperasiann diperlukan pemograman jumlah titik tik yang akan di bidik pada alat.

Hasil rekap data kepuasan materi pelatihan alat ukur tanah, yang diberikan melalui whatshaap yang dinyatakan dari Tabel 2, peserta pelatihan menjawab $95 \%$ materi sangat memuaskan, dengan menyatakan materi yang disampaikan mudah dipahami, bermanfaat dan memberi motivasi pada pekerjaan di lapangan serta pelaksanaan pemahaman materi sesuai dengan kegiatan. Sedang hasil rekap data kepu asan pada pemateri pelatihan alat ukur tanah peserta menyatakan cukup baik, karena ada jawabab $89 \%$ dari peserta yang menyatakan kesiapan penyampaian materi, ketepatan waktu kehadiran dan berupaya membangkitkan minat peserta pada saat pemahaman materi yang di sampaikan.

Kegiatan hasil pelaksanaan pengabdian kepada masyarakat tersebut mampu memberikan suatu nilai tambah bagi guru untuk 1) penerapan pengembangan alat total stasion di lapangan pada 
pembelajaran teori dan pratik bagi siswa 2) menyiapkan lulusan peserta didik dalam bekerja di dunia industri, sehingga lulusan SMK dapat bekerja secara mandiri, tim dengan baik dan benar yang berakibat ekonomi, perubahan perilaku dalam kerja sama. Kegiatan pengabdian dalam jangka panjang mampu memberi perubahan bagi pihak sekkolah, guru dan peserta didik pada jangka panjag dan pendek sebagai berikut

Tabel 5. Hasil Rekap Data Kepuasan Pemateri Pelatihan Alat Ukur Tanah

\begin{tabular}{|c|c|c|}
\hline Pencapaian & Jangka Pendek & Jangka Panjang \\
\hline $\begin{array}{l}\text { SMK Cabdin } \\
\text { Pendidikan } \\
\text { Jombang }\end{array}$ & $\begin{array}{l}\text { Tersusun Indikator kelulusan } \\
\text { kompetensi Mata pelajaran } \\
\text { IUT }\end{array}$ & Nilai KKM mata pelajaran IUT \\
\hline \multirow[t]{2}{*}{ Guru } & $\begin{array}{l}\text { Memahami indikator materi } \\
\text { IUT }\end{array}$ & $\begin{array}{l}\text { Siswa dapat menerapan alat IUT } \\
\text { secara mandiri dan Tim di dudin } \\
\text { pembangunan konstruksi }\end{array}$ \\
\hline & $\begin{array}{l}\text { Memahami kerja Tim untuk } \\
\begin{array}{l}\text { keberhasilan } \\
\text { dengan benar }\end{array}\end{array}$ & $\begin{array}{l}\text { Mengevaluasi hasil pengukuran sesuai } \\
\text { dengan fungsi dan tujuan } \\
\text { pembangunan konstruksi atau } \\
\text { pembukaan/pengembangan lahan }\end{array}$ \\
\hline
\end{tabular}

\section{KESIMPULAN}

Pelaksanaan pelatihan Pengolahan Data Hasil Pengukuran Waterpass, Theodolit, Totai Station bagi Guru Teknik Konstruksi dan Properti SMK Wilayah Kabupaten Jombang \& Sekitarnya, dari 10 SMKN negeri wilayah Jombang dengan 49 peserta dapat disimpulkan bahwa:

Keunggulan kegiata PKM terlaksana dengan baik, ditunjukan 1) jumlah peserta pendaftaran sama yaitu 49 dengan kehadiran hari pertama dan kedua $100 \%$, hari ketiha 99, $7 \%$ atau tidak hadi dua peserta, 2) pemahaman peserta ada kenaikan $15 \%$ pada pengukuran - pemrograman- ,pengolahan data pengukuran dan mengevaluasi pengukuran dengan alat ukur total stasion. 3) penggunaan alat total stasion ini di lapangan lebih efektif karena semuala menggunakan dua alat yang sifatnya manual menjadi satu alat yang sifatnya digital dan pengukuran lebih panjang seta hasilnta juga bisa langsung tergambar bila alat dilengkapi dengan software hasil pengukuran. yang merupakan pengembangan alat yang sudah ada yaitu alat waterpass dan theodolite.

Kelemahan hasil PKM 1) Pelaksanaan secara daring kurang optimum, meskipun sebagai praktik peserta diminta mengerjakan tugas membuat skema lokasi titik pengukuran, alat yang digunakan, hasil pengukuran dari peserta didik yang pernah dikerjakan, penggambaran dan mengevaluasi, hal ini ditunjukkan dengan ada nya kenaikan pemahamn kecil yaitu $14 \%$.. 2 ) peluang jangka panjang untuk kompetensi ketrampilan pepemograman dan dan pengukuran perlu ada pelatihan. 3) Hasil pemograman berupa excel dan bisa digambar dengan manual, sebagai peluang pengembangannya kedepan perlu pembelian software dengan hasil penggambaran dengan digital. 
Saran dari peserta antara lain: 1) Perlu di tambahi perbedaan gambar sketsa pengukuran dengan alat ukur total stasion dengan sketsa pengukuran menggunakan alat waterpas dan theodolite pada lahan yang sama, 2) Semoga diklat berlanjut, juga dengan materi yang lebih update, 3) Mengadakan pelatihan lanjutan dengan materi yang sama untuk pengukuran pengukuran volume galian dan timbunan serta pembuatan busur lapangan dengan pemberian modul tentang materi, 4) Selalu ada contoh untuk aplikasi dilapangan, misal proyek pengurukan tanah, proyek saluran air, trase jalan dan lain lain.

\section{UCAPAN TERIMAKASIH}

Terima kasih atas telah memberi dukungan financial terhadap pelaksanaan PKM ini kepada: Ketua LPPM Unesa, Dekan Fakultas Teknik Unesa, Cabdis Pendidikan Wilayah Jombang, kepala Sekolah SMKN Kudu Jombang atas diberi persetujuan dan dukungannya atas terlaksananya PKM dan terimakasih atas kerjasamanya pada Kepala Sekolah SMKN wilayah Jombang dan sekitarnya serta Tim PKM pelaksaan PKM yang telah memberi telah memberi dukungan financial terhadap pengabdian ini.

\section{DAFTAR PUSTAKA}

Amir, Z. (1998). Dasar-Dasar Pengukuran Terristris dan Pemetaan Situasi. Jurusan Teknik Sipil Fakultas Teknik Universitas Andalas.

Basuki, S. (2011). Ilmu Ukur Tanah (Issue 2). UGM press.

Muhamadi, M. (1987). Ilmu Ukur Tanah I. Fatek ITS.

Sosrodarsono, S., \& Takasaki, M. (1996). Pengukuran topografi dan teknik pemetaan. Pradnya Paramita.

Wolf., R. C. B. \& P. R. (1986). Dasar-Dasar Pengukuran 1 \& 2 Jakarta: Erlangga. (Issue 2). Erlangga.

Wongsotjitro. (1980). Ilmu Ukur Tanah. Jogyakarta: Kanisius (Issue 2). Kanisius. 